\title{
Characterization of Salmonella Gallinarum isolates from backyard poultry by polymerase chain reaction detection of invasion (invA) and Salmonella plasmid virulence (spvC) genes
}

\author{
Susmita Pal, Samir Dey, Kunal Batabyal, Abhiroop Banerjee, Siddhartha Narayan Joardar, \\ Indranil Samanta and Devi Prasad Isore \\ Department of Veterinary Microbiology, West Bengal University of Animal and Fishery Sciences, Belgachia, \\ Kolkata - 700 037, West Bengal, India. \\ Corresponding author: Samir Dey, e-mail: samirddy@yahoo.co.in \\ Co-authors: SP: sushvet60@gmail.com, KB: drkb.micro@gmail.com, AB: abdocarp@gmail.com, \\ SNJ: joardar69@gmail.com, IS: isamanta76@gmail.com, DPI: deviprasadisore@gmail.com \\ Received: 07-02-2017, Accepted: 13-06-2017, Published online: 23-07-2017
}

doi: 10.14202/vetworld.2017.814-817 How to cite this article: Pal S, Dey S, Batabyal K, Banerjee A, Joardar SN, Samanta I, Isore DP (2017) Characterization of Salmonella Gallinarum isolates from backyard poultry by polymerase chain reaction detection of invasion (invA) and Salmonella plasmid virulence (spvC) genes, Veterinary World, 10(7): 814-817.

\begin{abstract}
Aim: The aim was to characterize Salmonella enterica serovar Gallinarum isolated from backyard poultry by polymerase chain reaction (PCR) detection of virulence genes invasion (invA) and Salmonella plasmid virulence C (spvC).

Materials and Methods: Two strains of Salmonella serovar Gallinarum isolates used in this study were obtained from an outbreak of fowl typhoid in backyard Vanaraja fowl. PCR technique was used for detection of invA and $s p v \mathrm{C}$ genes using standard methodology. The invA PCR product from one representative isolate was sequenced and compared with other related Salmonella serovars in GenBank data.
\end{abstract}

Results: Salmonella Gallinarum produced expected amplicons of invA and $s p v \mathrm{C}$ gene products. Nucleotide sequence of 285 bp invA gene was deposited in GenBank with accession no. KX788214. Sequence analysis of invA gene was found conserved in Salmonella serovars and demonstrated 100\% homology with closely related serovars of Salmonella.

Conclusion: Invasion gene (invA) was found to be highly conserved in Salmonella Gallinarum and highly similar with closely related serovars. The isolates also contained plasmid-mediated spvC gene indicating possession of virulence plasmid.

Keywords: invA, polymerase chain reaction, Salmonella Gallinarum, Salmonella plasmid virulence $C$, virulence genes.

\section{Introduction}

Fowl typhoid (FT) is disease of major economic significance in many countries of Asia, Africa, Central and South America [1]. It is an endemic disease of poultry in India with occasional outbreaks [2-4]. The pathogen Salmonella enterica serovar Gallinarum can colonize and cause disease in various domestic and wild birds. The pathogen can get transmitted by both horizontal and vertical routes. The majority of virulence genes of Salmonella are clustered in a region distributed over the chromosome, called Salmonella pathogenicity islands (SPI). A total of 19 SPI have been described with SPI-1 to SP-5 being present in most serovars and others were being less widely distributed [5]. Besides, one large plasmid of approximately $85 \mathrm{~kb}$ in Salmonella Gallinarum have the ability of strains to produce high mortality in chickens [6] and Salmonella plasmid virulence (spv) locus that carries the $s p v$ genes were reported to be present

Copyright: Pal, et al. Open Access. This article is distributed under the terms of the Creative Commons Attribution 4.0 International License (http://creativecommons.org/licenses/by/4.0/), which permits unrestricted use, distribution, and reproduction in any medium, provided you give appropriate credit to the original author(s) and the source, provide a link to the Creative Commons license, and indicate if changes were made. The Creative Commons Public Domain Dedication waiver (http://creativecommons.org/ publicdomain/zero/1.0/) applies to the data made available in this article, unless otherwise stated. in Salmonella Gallinarum-Pullorum and few other non-typhoid Salmonella serovars, namely, Salmonella Abortusovis, Salmonella Choleraesuis, Salmonella Dublin, Salmonella Enteritidis, and Salmonella Typhimurium, and Salmonella Sendai [7] and absent in typhoid serovars Typhi and Paratyphi [8].

The chromosomally located invasion gene (invA) being thought to trigger the invasion of Salmonellae into cultured epithelial cells [9], while an operon $(s p v \mathrm{RABCD})$ in plasmid containing five genes, involved in intra-macrophage survival of Salmonella [10]. Characterization of Salmonella serovars has been carried out previously by various researchers by polymerase chain reaction (PCR) assay of different virulence factors [11-13], but the study was less reported with Salmonella Gallinarum particularly from backyard poultry.

The current study was aimed to characterize Salmonella Gallinarum obtained from backyard poultry by detection of virulence genes invA and spvC.

\section{Materials and Methods}

Ethical approval

As per the Committee for the Purpose of Control and Supervision on Experiments on Animals (CPCSEA) guidelines, this study does not require ethical approval from Institute Animal Ethics Committee. 


\section{Bacterial strains}

Two isolates of Salmonella Gallinarum (WBSG-1, WBSG-2) obtained from the Department of Veterinary Microbiology, West Bengal University of Animal and Fishery Sciences, Kolkata, from an outbreak of FT in Vanaraja fowl were used. The isolates were serotyped with antigenic structure $(9,12:-:-)$ at National Salmonella and Escherichia Centre, Kasauli, India.

\section{Preparation of culture lysate}

Bacterial culture lysate was prepared as described previously [14] with little modification. $1 \mathrm{ml}$ of overnight broth culture of Salmonella Gallinarum was taken in a sterile $1.5 \mathrm{ml}$ microcentrifuge tube (Tarsons, India) and centrifuged at $6000 \mathrm{rpm}$ for $5 \mathrm{~min}$. The pellet was washed twice with Tris-ethylenediaminetetraacetic acid (EDTA) buffer and was re-suspended in $1 \mathrm{ml}$ Tris-EDTA buffer. Then, the culture was boiled for $10 \mathrm{~min}$ followed by chilling in ice. The cell debris was removed by centrifugation at $6000 \mathrm{rpm}$ for $5 \mathrm{~min}$. Then, the supernatant was stored at $-20^{\circ} \mathrm{C}$ for further use as template DNA.

\section{PCR assay}

Salmonella specific primers described previously [15], the forward primer S139 and reverse primer S141 (Table-1) based on the invA gene of Salmonella were used. The amplification of the invA gene fragment was carried out as described earlier with little modifications [16]. The PCR was carried out with a $25 \mu \mathrm{l}$ amplification mixture consisting of $3 \mu \mathrm{l}$ template DNA, $5 \mu 1$ of $\times 5$ GoTaq $^{\circledR}$ Flexi buffer, $0.5 \mu$ of deoxynucleotide triphosphates (10 mM each), $1.6 \mu \mathrm{l}$ of $25 \mathrm{mM} \mathrm{MgCl}, 1 \mu \mathrm{l}$ of $10 \mu \mathrm{M}$ each primer and $0.3 \mu 1$ of $\mathrm{GoTaq}^{\circledR}$ DNA polymerase (Promega, USA), and $12.6 \mu 1$ nuclease free water. Amplification was conducted in a thermocycler (Mastercycler personal, Eppendorf, Germany). The cycle condition consisted an initial denaturation $94^{\circ} \mathrm{C}$ for 1 min followed by 35 cycles of denaturation at $94^{\circ} \mathrm{C}$ for $60 \mathrm{~s}$, annealing at $64^{\circ} \mathrm{C}$ for $30 \mathrm{~s}$, and elongation at $72^{\circ} \mathrm{C}$ for $30 \mathrm{~s}$ with 7 min final extension period at $72^{\circ} \mathrm{C}$. The amplified products were visualized by agarose gel electrophoresis containing $1.5 \% \mathrm{w} / \mathrm{v}$ agarose (SRL, India) with ethidium bromide $(0.5 \mu \mathrm{g} / \mathrm{ml})$ and detected by gel documentation system (UVP, UK).

For $s p v \mathrm{C}$ gene, another set primer was used (Table-1) [7]. The amplification conditions for the $s p v \mathrm{C}$ gene fragment being similar as described for invA gene except the annealing temperature was $58^{\circ} \mathrm{C}$.

\section{Nucleotide sequencing of invA gene}

Positive amplification from a PCR reaction of invA gene from one representative isolate (WBSG1) was purified with DNA gel/PCR purification mini kit (Xcelris, India). Both strands of purified PCR product were sequenced with forward and reverse primers for inv A gene in an ABI $3730 \mathrm{XL}$ automated sequencer (Applied Biosystems) in custom sequencing facility of Xcelris, India. Sequence obtained was analyzed, and homology searches were conducted using the BLAST algorithm (www.ncbi.nlm.nih.gov/BLAST).

\section{Results}

Amplicons of invA and spvC virulence genes were observed in agarose gel as $\sim 284 \mathrm{bp}$ and $\sim 571 \mathrm{bp}$ products, respectively (Figure-1).

Nucleotide sequence of invA gene of Salmonella Gallinarum strainWBSG1 obtained in this study was analyzed and $285 \mathrm{bp}$ sequences deposited with NCBI under GenBank accession number KX788214. Sequence alignment with BLAST revealed that invA gene of Salmonella Gallinarum strain WBSG1 was highly similar $(100 \%)$ with some other poultry serovars such as Salmonella enterica serovar Gallinarum strain 9184 (accession no. CP019035.1) and Salmonella Enteritidis strain OLF 00D 98987-1 (accession no. CP011942.1) isolated elsewhere.

\section{Discussion}

Detection of invasion gene of Salmonella by PCR-based assays may be useful for rapid pathogen

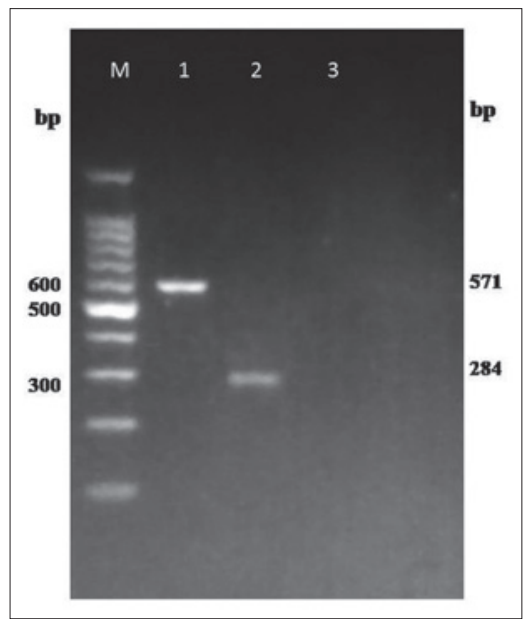

Figure-1: Polymerase chain reaction amplification of virulence genes invA and Salmonella plasmid virulence C (spvC) of Salmonella Gallinarum isolates. Lane M: $100 \mathrm{bp}$ DNA ladder, Lane 1: invA gene (strain WBSG1), Lane 2: spvC gene (strain WBSG2), Lane 3: Negative control.

Table-1: Oligonucleotides (primers) used for detection of virulence genes (invA and spvC) of Salmonella Gallinarum.

\begin{tabular}{lllcl}
\hline Genes & Primer & Oligonucleotides $\left(\mathbf{5}^{\prime} \mathbf{-} \mathbf{3}^{\prime}\right)$ & Amplification product (bp) & References \\
\hline invA & S139 & GTG AAA TTA TCG CCA CGT TCG GGC AA & 284 & {$[15]$} \\
& S141 & TCATCGCACCGTCAAAGGAACC & & \\
spvC & SPV-1 & ACTCCTTGCACAACCAAATGCGGA & 571 & {$[7]$} \\
& SPV-2 & TGTCTTCTGCATTCGCCACCATCA & &
\end{tabular}

spv=Salmonella plasmid virulence 
identification as well. Molecular identification of Salmonella sp. with invA gene primer set S139-S141 conforms to be international standard [17-19] with very high specificity [15]. However, choosing suitable primers are important as the primer sets targeting different sequences within invA gene [7], often resulted in non-specific amplification with the fecal and gut-associated bacteria [20]. In one study, Salmonella isolates belonging to serotypes Anatum, Enteritidis and Amsterdam were also reported negative for the invA gene using those primers [21].

High prevalence of invA virulence gene in Salmonella serovars has also been reported by other workers [22,23]. We found invA gene was $100 \%$ similar with other Salmonella serovars. Other studies also reported similar results [24], which were expected since the invasion gene (invA) is conserved among Salmonella serovars. Serovar Enteritidis, Dublin, and Gallinarum were reported to be closely related where serovar Dublin and Gallinarum diverging independently from an Enteritidis-like ancestor [25].

In this study, both Salmonella Gallinarum isolates were positive to $s p v \mathrm{C}$ gene. This finding was similar with a study in Kashmir where all isolates of Salmonella from poultry harbored virulence genes $i n v \mathrm{~A}$ and $s p v \mathrm{C}$ [26]. However, less prevalence of $s p v$ genes was noticed in Salmonella serovars by several workers $[9,27,28]$. In a study with 37 Salmonella comprising serovar Enteritidis $(n=12)$ and Typhimurium $(n=24)$ originated from pork and slaughterhouse environment, all have produced $284 \mathrm{bp}$ invA gene, but no $s p v \mathrm{C}$ gene [23]. In another study, a high prevalence $(88.6 \%)$ of $s p v \mathrm{~A}, s p v \mathrm{~B}$, and $s p v \mathrm{C}$ genes was observed in S. Enteritidis from poultry source [13]. One main function of the $s p v$ operon is to potentiate the systemic spread of the pathogen [29], and these genes can restore pathogenicity for systemic spread in plasmid-cured strains [30]. The spv region contains three genes required for the virulence phenotype in mice; the positive transcriptional regulator $s p v \mathrm{R}$ and two structural genes $s p v \mathrm{~B}$ and $s p v \mathrm{C}$ [8]. Mutations in $s p v \mathrm{C}$ and $s p v \mathrm{D}$ genes cause various (allele-specific) defects in Salmonella virulence [31].

\section{Conclusion}

Invasion gene (invA) was found to be highly conserved in Salmonella Gallinarum and highly similar with closely related serovars. The isolates also contained $s p v \mathrm{C}$ gene indicating possession of plasmid virulence.

\section{Authors' Contributions}

$\mathrm{SP}, \mathrm{KB}$, and SD planned and designed the study. The experiment was conducted by SP, AB, and IS, data analysis was performed by SNJ, SD, and DPI. All authors participated in the draft and revision of the manuscript. All authors read and approved the final manuscript.

\section{Acknowledgments}

The authors are grateful to the Vice-Chancellor, Director of Research, West Bengal University of Animal and Fishery Sciences and Dean, Faculty of Veterinary Science for providing necessary facilities and ICAR for financial assistance (Development Grant 7.1).

\section{Competing Interests}

The authors declare that they have no competing interests.

\section{References}

1. Barrow, P.A. and Freitas Neto, O.C. (2011) Pullorum disease and fowl typhoid-new thoughts on old diseases: A review. Avian Pathol., 40: 1-13.

2. Rajagopal, R. and Mini, M. (2013) Outbreaks of salmonellosis in three different poultry farms of Kerala, India. Asian Pac. J. Trop. Biomed., 3: 496-500.

3. Kumari, D., Mishra, S.K. and Lather, D. (2013) Pathomicrobial studies on Salmonella Gallinarum infection in broiler chickens. Vet. World, 6(10): 725-729.

4. Gupta, R., Jindal, N., Arora, D., Singh, M. and Kapoor, P.K. (2016) Detection of Salmonella Typhimurium, Salmonella Enteritidis and Salmonella Gallinarum from suspected cases of fowl typhoid in poultry in Haryana. Indian Vet. J., 93(7): 44-47.

5. Foley, S.L., Lynne, A.M. and Nayak, R. (2008) Salmonella challenges: Prevalence in swine and poultry and potential pathogenicity of such isolates. J. Anim. Sci., 86: E149-E162.

6. Barrow, P.A., Simpson, J.M., Lovell, M.A. and Binns, M.M. (1987) Contribution of Salmonella Gallinarum large plasmid toward virulence in fowl typhoid. Infect. Immun., 55: 388-392.

7. Chiu, C.H. and Ou, J.T. (1996) Rapid identification of Salmonella serovars in feces by specific detection of virulence genes, invA and $s p v \mathrm{C}$, by an enrichment broth culture-multiplex PCR combination assay. J. Clin. Microbiol., 34(10): 2619-2622.

8. Guiney, D.G. and Fierer, J. (2011) The role of the spv genes in Salmonella pathogenesis. Front. Microbiol., 129: 1-10.

9. Swamy, S.C., Barnhart, H.M., Lee, M.D. and Dreesen, D.W. (1996) Virulence determinants invA and $s p v \mathrm{C}$ in Salmonellae isolated from poultry products, wastewater, and human sources. Appl. Environ. Microbiol., 62: 3768-3771.

10. Rychlik, I., Gregorova, D. and Hradecka, H. (2006) Distribution and function of plasmids in Salmonella enterica. Vet. Microbiol., 112: 1-10.

11. Oliveira, S.D., Rodenbusch, C.R., Michael, G.B., Cardoso, M.I.R., Canal, C.W. and Brandelli, A. (2003) Detection of virulence genes in Salmonella Enteritidis isolated from different sources. Braz. J. Microbiol., 34 Suppl $1: 123-124$

12. Okamoto, A.S., Filho, R.L.A., Rocha, T.S., Menconi, A. and Marietto-Gonçalves, G.A. (2009) Relation between the $s p v \mathrm{C}$ and invA virulence genes and resistance of Salmonella enterica serotype Enteritidis isolated from avian material. Int. J. Poult. Sci., 8(6): 579-582.

13. Kaushik, P., Anjay, K.S., Bharti, S.K. and Dayal, S. (2014) Isolation and prevalence of Salmonella from chicken meat and cattle milk collected from local markets of Patna, India. Vet. World, 7(2): 62-65.

14. Shanmugasamy, M., Velayutham, T. and Rajeswar, J. (2011) InvA gene specific PCR for detection of Salmonella from broilers. Vet. World, 4(12): 562-564.

15. Rahn, K., De Grandis, S.A., Clarke, R.C., McEwen, S.A., Galan, J.E., Ginocchio, C., Curtiss, R. $3^{\text {rd }}$. and Gyles, C.L. (1992)Amplification of an invAgene sequence of Salmonella Typhimurium by polymerase chain reaction as a specific 
method of detection of Salmonella. Mol. Cell. Probes, 6(4): 271-279.

16. Dey, S., Mahanti, A., Batabyal, K., Joardar, S.N., Samanta, I., Isore, D.P. and Pakhira, M.C. (2016) Identification and antimicrobial susceptibility of Salmonella Gallinarum isolated from fowl typhoid outbreak in backyard poultry. Explor. Anim. Med. Res., 6(1): 63-67.

17. Malorny, B., Hoorfar, J., Bunge, C. and Helmuth, R. (2003) Multicenter validation of the analytical accuracy of Salmonella PCR: Towards an international standard. Appl. Environ. Microbiol., 69: 290-296.

18. Ezzat, M.E., Shabana, I.I., Esawy, A.M. and Elsotohy, M.E. (2014) Detection of virulence genes in Salmonella serovars isolated from broilers. Anim. Vet. Sci., 2(6): 189-193.

19. El-Tawwab, A.A.A., Ammar, A.M., Ali, A.R., El-Hofy, F.I. and Sayed, A.M.E. (2013) Detection of common (invA) gene in salmonellae isolated from poultry using polymerase chain reaction technique. Benha Vet. Med. J., 25(2): 70-77.

20. Ziemer, C.J. and Steadham, S.R. (2003) Evaluation of the specificity of Salmonella PCR primers using various intestinal bacterial species. Lett. Appl. Microbiol., 37: 463-469.

21. Turki, Y., Mehr, I., Ouzari, H., Khessairi, A. and Hassen, A. (2014) Molecular typing, antibiotic resistance, virulence gene and biofilm formation of different Salmonella enterica serotypes. J. Gen. Appl. Microbiol., 60(4): 123-130.

22. Karmi, M. (2013) Detection of virulence gene (invA) in Salmonella isolated from meat and poultry products. Int. J. Genet., 3(2): 7-12.

23. Chaudhary, J.H., Nayak, J.B., Brahmbhatt, M.N. and Makwana, P.P. (2015) Virulence genes detection of Salmonella serovars isolated from pork and slaughter house environment in Ahmedabad, Gujarat. Vet. World, 8(1): 121-124.

24. Samanta, I., Joardar, S.N., Das, P.K., Sar, T.K.,
Bandyopadhyay, S., Dutta, T.K. and Sarkar, U. (2014) Prevalence and antibiotic resistance profiles of Salmonella serotypes isolated from backyard poultry flocks in West Bengal, India. J. Appl. Poult. Res., 23: 536-545.

25. Porwollik, S., Santiviago, C.A., Cheng, P., Florea, L., Jackson, S. and McClelland, M. (2005) Differences in gene content between Salmonella enterica serovar Enteritidis isolates and comparison to closely related serovars Gallinarum and Dublin. J. Bacteriol., 187: 6545-6555.

26. Mir, I.A., Wani, S.A., Hussain, I., Qureshi, S.D., Bhat, M.A. and Nishikawa, Y. (2010) Molecular epidemiology and in vitro antimicrobial susceptibility of Salmonella isolated from poultry in Kashmir. Rev. Sci. Tech. Off. Int. Epiz., 29(3): 677-686.

27. Ammar, A.M., Mohamed, A.A., El-Hamid, M.I.A. and El-Azzouny, M.M. (2016) Virulence genotypes of clinical Salmonella serovars from broilers in Egypt. J. Infect. Dev. Ctries., 10(4): 337-346.

28. Purkayastha, A., Borah, P., Sharma, R.K. and Borah, P.P. (2015) Multiplex PCR for detection of virulence gene profiles of Salmonella isolates from animals and man. Indian J. Appl. Res., 5(12): 142-144.

29. Heithoff, D.M., Shimp, W.R., Lau, P.W., Badie, G., Enioutina, E.Y., Daynes, R.A., Byrne, B.A., House, J.K. and Mahan, M.J. (2008) Human Salmonella clinical isolates distinct from those of animal origin. Appl. Environ. Microbiol., 10: 1757-1766.

30. Gulig, P.A., Danbara, H., Guiney, D.G., Lax, A.J., Norel, F. and Rhen, M. (1993) Molecular analysis of $s p v$ virulence genes of the Salmonella virulence plasmid. Mol. Microbiol., 6: $825-830$

31. Rotger, R. and Casadesús, J. (1999) The virulence plasmids of Salmonella. Int. Microbiol., 2: 177-184. 